\title{
EXILES AND ARRIVALS IN CHRISTOPHER COLUMBUS AND WILLIAM BRADFORD*
}

\author{
JosÉ MARÍA RodRíGUEZ GARCÍA \\ Universidade da Coruña
}

I will be concerned in this essay with a few key passages in Christopher Columbus's Journal of the First Voyage (1492-1493) and William Bradford's Of Plymouth Plantation (1630-1650; pub. 1856) in which the two authors invest their respective plans for a voyage across the ocean with a transcendental significance, linking them to important movements of population caused by religious persecution. In both cases persecution alternately takes on positive and negative connotations: depending on the perspective being adopted, it can be a sign of divine favor or a sign of divine punishment. While Columbus sees the expulsion of the Jews of Sepharad and the fall of Granada's last Moorish king, Boabdil, as an omen of the discovery of a Christian paradise on earth - the original Garden of Eden- Bradford sees the exodus of the Pilgrim Fathers through England, Holland, and America as the ultimate test of faith in divine Providence that the English Israel must undergo. In the course of the fifteenth century, as «Israel» and «the Jewish people» acquired the cultural status of the rejected other of Christendom, they also became the symbol of an errant people continually striving for an interpretation of their own deferred destiny.

Sixteenth -and seventeenth- century theories of national election inspired by the Reconquest of Spain and by massive religious migrations often emphasized two interdependent historical time frames, each deploying a different understanding of history and progress, and each promoting also a characteristic sense of purpose. This dual time scheme appears in Andrés de Bernáldez, Christopher Columbus, Tommaso Campanella, Robert Cushman, John Eliot, John Winthrop, and Edward Johnson, among others. On the one hand, only the elect people were destined to achieve terrestrial success in this world, their lives being the culmination of a completed cycle

* This essay is part of a collective research project funded by the Xunta de Galicia (Spain) for the years 1998-2000 (grant code: XUGA 10404A98). 
of fall and redemption. ${ }^{1}$ Thus, both Columbus and the New England Puritans thought they were living in the penultimate moment of human history-the time immediately preceding the revelation of God's grand design and the Second Coming of the Messiah. On the other hand, however, the same Renaissance theorists also insisted that all contemporary events amounted to simply one more episode in the progressive history of redemption of all humankind, a history that was to have further moments of redemption and declension in future generations. As these cataclysmic changes took place, the prerogative of imperium or dominion was transferred, according to the open-ended logic of translatio imperii, from one people to another: in each historical period God chose one people over another as his main agent to reunite the world under the rule of Christ.

Although Bradford makes as many references to God's acts of Providence as a Robinson Crusoe, he does not indulge in frightful anticipations of the Apocalypse (representations of the end of the world and Judgment Day), as the third-generation Puritans will do toward the end of the seventeenth century. Bradford professed the ideology of Separatist Congregationalism, in which the individual Christian sought a direct contact with God, uncontaminated by political institutions. This persuasion notwithstanding, he knew from the beginning that several churches were to rival with Separatist Plymouth. The rival forms of organized worship included the Church of England (indicted in the opening two chapters and mentioned in the Mayflower Compact) and Thomas Morton's bacchanalian revels (described in detail in the Merrymount chapter). ${ }^{2}$ The Pilgrims' penchant for states of extreme spiritual alert was reinforced by their living in close proximity to the Native Indians and by the establishment of the first Nonseparatist Puritan colony in Massachusetts in 1630, the same year in which Bradford set out to write his chronicle.

Like most seventeenth-century Christians, regardless of their churches, Bradford seems aware of the insignificant role allotted to him in the unfolding of God's preordained plan for the entire history of the world from the moment of creation to the Apocalypse. At the same time, however, he knows he exists in the microhistory of the Puritan nation, which is specifically informed by a smaller pattern of periodic changes of fortune, of loss and recovery or great peril and triumph. As noted by Walter P. Wenska, the Pilgrims, «simply by being part of history, were part of the first pattern, and their experience until their arrival in New England was part of the second» (158). They were living in the autumn of world, at the end of history, and believed that the advent of the messianic rule over the world (the acknowledged climax of the Millennium), although not immediately close at hand, was bound to occur sometime in the near future. The Puritans' slow but steady march toward the Millennium in turn authorized their claim to moral superiority over Israel, and to the New World's superiority over the biblical Canaan: «they declared the New World another promised land, counterpart of Canaan of old but greater, because closer to the

1. See Pagden 51-54; Liss 263-90; Zagorin 163-71; Bercovitch, «Puritan New England Rhetoric» 64-69; Rites of Assent 140-41.

2. On Bradford's and Morton's verbal indictments of each other, see Cartelli. Morton's views on the Spartan discipline decreed at Plymouth appear in his New' English Canaan (1637). 
millennium, and they documented their claim with scriptural prophecies as befit a chosen people» (Bercovitch, Rites of Assent 77).

The use of a dual time scheme in the interpretation of history helps explain the alternate feelings of optimism and despair that inform much of early Puritan literature. The emphasis on wordly success as a sign of divine favor also explains why neither the average Spanish explorer nor the average Puritan felt that by pursuing his own interest he was betraying the teachings of his religion. While it is true that the capitulación or charter privileges issued to Columbus did not entrust him with any evangelical mission, and that it was the Admiral who first invoked one such purpose in his widely circulated «Letter of 1492» (also known as «Prologue to the Sovereigns»), the invocation had the effect of endowing all future enterprises with the appearance of a mercantile crusade. Columbus, for one, wanted to claim the Indies back from the hands of the pagans, assuming that the trading expeditions to the Orient were only a first step toward evangelizing Asia. As Margarita Zamora has put it, with Columbus it became customary to replace the earlier, medieval purposes of «comprar, trocar, hallar, haber (buy, barter, locate, possess)» with the modern ones of «ganar, descubrir, regir (acquire, discover, govern)» (Reading Columbus 27-28). ${ }^{3}$ This plan was inspired by the process of Christian Reconquest of Spain just completed with the fall of Granada in 1492. If the conquest of America soon became a displacement and a continuation of the medieval Reconquest, the Native Indians became willy-nilly the successors, in the Castilian imaginary, of the bellicose Moors of Muslim Spain. ${ }^{4}$

Together with the overtly commercial interests supported by the Castilian and English monarchs, one must also look at the political and spiritual reasons for the colonization of American territories that Columbus and Bradford adduce in their writings. It is interesting to note that, despite the century-and-a-half that separates Columbus's first voyage from Bradford's Mayflower expedition, the two authors invoke the same two forms of religious zeal as the immediate causes prompting their crossing of the ocean. The first cause is the desire to convert-to appeal to the minds and hearts of the unbelievers (the peoples of the Far East in the case of Columbus, and the Native Indians and Virginia and New England Anglicans in the case of the Puritans). The process of conversion was to be carried out by preaching and the force of example, eventually to bring unbelievers into the community of belief. The second cause was the more simple-minded desire to ensure by military and political means the safety and independence of one's own religious community (Christendom at large in the case of Columbus), and, better still, its predominance over others. Bradford, however, did not profess the same view of the nation put forth by the leaders of the Church of England. Because Bradford and the Separatists publicly refused allegiance to any institutional authority, including the Middle-Way Congregationalists (e.g., John

3. On Columbus's use of the "descubrir y ganar» topos, see Kadir 69-72. For its ironic occurrence, as econquistados y perdidos, in Bcrnal Díaz del Castillo, who finished writing his eycwitness account of the Spanish eunquest of New Spain some seventy-five years after Columbus's first voyage, see Rodríguez García 490-91.

4. This is now a locus classicus in Hispanic historiography. For a good summary of the main thesis, see Perez 58-62. 
Winthrop) and the Presbyterians (the representative ecclesiastical government put in practice by the Church of Scotland), they did not envision the immediate appearance of a nation that mediated between their small scattered, self-governing congregations and the New England Canaan. Instead, they «hoped to join the progress of the 'universal invisible church' in small congregations, modelled after the first Christian communities» (Bercovitch, Rites of Assent 73). The Separatists for the most part accepted the as-yet unredeemed nature of humankind, and so did not explicitly address the imminence of the Apocalypse, as later Puritans would do.

Columbus had a slightly different view of human history. He thought that America, given its exuberant landscapes and riches, was the original Garden of Eden, which he even dared to locate somewhere up the Orinoco River (Zamora, Reading Columbus 137-51). This important difference goes a long way toward explaining why Columbus and Bradford have very rarely been brought together, in the same discussion on the millennial rhetoric of colonialism, by either historians or literary scholars. To be sure, Bradford (unlike the Nonseparatists John Winthrop and John Eliot) was more interested in having his community repeat the errand of the Old Testament prophets than he was in paving the way for the doctrinal arrival at the Terrestrial Paradise, the New England Canaan. In fact, for the older, more introverted Bradford, if he could lay his eyes on a new Canaan at all, this was to be found in a text. In a short piece often referred to as the «Jewish Preface» to his «Hebrew Exercises," which itself can be read as a belated postcript to Of Plymouth Plantation, the Governor explains that while Moses discovered Canaan, he, Bradford, is content with discovering the original meanings contained in the Hebrew Scripture:

Though I am grown aged, yet I have had a longing desire, to see with my owne eyes, som[e]thing of that most ancient language, and holy tongue, in which the Law, and oracles of God were write; and in which God, and angels, spake to the holy patriarks of old time; and what names were given to things from the creation. And though I cannot attaine to much herein, yet I am refreshed, to have seen some glimpse hereof; (as Moyses saw the land of Canaan a farr off) My aime and desire is, to see how the words and phrases lye in the holy texte; and to discerne somewhat of the same, for my owne contente. ${ }^{5}$

5. The text was first published, in a facsimile reproduction preceded by a critical introduction, by Isidore S. Meyer in 1949. It is transcribed in a slightly modernized rendering by Franklin on p. 178 of his study, from where I have taken it. 
Bradford and Columbus seem equally fond of interpreting events in light of scriptural doctrine, setting those events either in contrast or in parallel to similar episodes narrated in the Bible. Contrary to Bradford, Columbus also identifies his own travels of exploration with the physical discovery of the ancient Canaan, the Terrestrial Paradise promised by God to David. Here I wish to argue that the frequency with which both authors resort to the tropes of exodus and errancy, their emphasis on what it means to be always on the move (both spiritually and socially), is what brings them together at the same time as it sets them apart from other figures like John Winthrop and Hernán Cortés. The only modern historian who has briefly touched on Columbus apropos of Bradford, Wayne Franklin, has noted other points of contact, although by no means does he attempt a thorough comparison. First, the two governors ended their careers reverting to a state approaching self-defensive solipsism, unable to cope with the competitors that launched alternative projects of exploration and settlement (Winthrop eclipsed Bradford; Vespucci rivaled with Columbus), and, in Columbus's case, with legends of «unknown pilots» who landed on America's mainland before the Admiral. 6 And second, as cosmographers and theologians, both looked for a "paradise of the mind,» Columbus imagining it in the recondite source of the Orinoco while Bradford displaced it into his study of the Hebrew language, to which he devoted his last scholarly efforts (Franklin 177-78, 182-83). Since Columbus was not granted the opportunity to search for the Venezuelan Canaan, which he identified with the lost Garden of Eden, he turned to the composition of the Book of Prophecies (Libro de las profecias [1501-1502]). This work, like Bradford's Hebrew studies, provided its author with some consolation for the failure of his plan for the establishment of an uninterrupted lineage of saints in the New World. ${ }^{7}$ As records of a religious patriarch struggling to overcome his feelings of loss and nostalgia, Bradford's comments on the Hebrew Bible and Columbus's annotation of select prophecies take their authors out of historical contingency and into the realm of the imagination. They both enact a nominalist return to the language of revelation, in which ideals cannot be tainted or thwarted, and in which words are spiritual events in their own right.

By contrast with Columbus, whose expedition was sponsored directly by the all-powerful crown of Castile-Aragon, Bradford did not have the full support of the same state power that granted him a charter in the first place. Yet the Plymouth Governor, a largely self-taught man and a religious ideologue like Columbus, had also a medieval imagination that made him look for analogies between biblical and

6. On the early efforts to dispossess Columbus, even in his own lifetime, of the honorific title of «discoverer,» see Fernández-Armesto 185-87.

7. The Libro de las profecias, which was compiled under Columbus's direction, is best described as a notebook of Bible studies, a repository of source materials that the Admiral occasionally used to argue for the imminent fulfillment of other prophecies foretold in the Bible and in the works of such ancient authorities as Seneca and Augustine. The complete text of the Libro was first published in the rare 1892-94 Italian anniversary edition of Columbus's papers (Raccolta di documenti), was translated into Spanish in 1984, and translated into English for the first time only in 1991 , in anticipation of the Columbian quincentennial. 
contemporary episodes, read prophecy as history, and present personal convictions as revealed truths. An important biblical episode that caught Bradford's imagination was the narration, in the Old Testament, of the exodus of the Israelites from Egypt and their crossing of a wilderness of waters (the Red Sea) in search of the Terrestrial Paradise. ${ }^{8}$ A crucial point to make here is that Bradford was from the outset more concerned with the possibility that the Separatists escape the bondage of body and conscience represented by European Catholicism and Lutheranism than he was with arriving at the Promised Land, for which his Puritans were not yet prepared. Accordingly, he uglifies America to avoid the temptation to see in it signs of Paradise. He also famously compares himself to a new Moses who, after leading his pilgrim saints through a «sea of troubles» and a «desolate wilderness» cannot «go up to the top of Pisgah to view a more goodly country to feed [his people's] hopes» (69). From its first occurrence in the book of the same title and in Deuteronomy, «Exodus» means the emancipation of God's chosen people from their bondage to an illegitimate ruler (the Pharaoh) by means of a departure from the land of the oppressor. Beginning in the early seventeenth century it also came to signify, according to the Oxford English Dictionary, any removal and relocation of a group of people because of religious, political, and even economic reasons.

Columbus, who came from a family of converso weavers and merchants and fancied himself, like Bradford, an interpreter of prophecies, also mentions Moses by name in the journal entry for 23 September 1492:

Como la mar estuviese mansa y llana, murmurava la gente diziendo que, pues por allí no avía mar grande, que nunca ventaría para volver a España. Pero después alçóse mucho la mar y sin viento, que los asombrava, por lo cual dize aquí el Almirante: «Así que muy neçessario me fue la mar alta, que no pareçió salvo el tiempo de los judíos cuando salieron de Egipto contra Moisén, que los sacava del captiverio.» (Varela ed., 23-24)

The sea was a flat calm, and the crew were complaining, saying that as the sea was never rough here there would never be a wind to take us home to Spain, but then they were astonished when a heavy sea rose with no wind, and the Admiral wrote accordingly: «So this heavy sea came very opportunely for me; it was just like the Jews, on their way out of Egypt, arguing with Moses as he led them out of captivity.» (Cummins ed., 89; trans. amended)

8. Gay observes in a footnote that the popularity of the «desolate wilderness» metaphor did not decline after Bradford. On the contrary, for later authors like Cotton Mather (who uses the word "wilderness» 94 times in the Magnalia Christi Americana [1702]), it became «an all-purpose, and herice almost meaningless, metaphor, embracing the American cnvironneri. tha temptation of Jesus. Luther's suffering in his exile, King David's wandering. and, above all, the children of Israel fleeing Egypt» $(29 \mathrm{n} 5)$. 
Consuelo Varela adds the following note to this passage: «¿Se identifica aquí Colón con Moisés? No hay que olvidar que emprende el viaje el mismo día de la expulsión de los judíos, y que parece ser que en el rol de esta primera navegación aparece gran cantidad de hebreos» (24 n22). Another episode from Scripture that also fascinated Columbus was the Lord's promise to King David of bringing the errancy of the Jewish nation to a conclusion by letting the Israelite king conquer the last of the four corners of the earth and build there a temple. I would like to propose that Columbus literalizes the relationship between the Lord and David in his own relationship with the Catholic Monarchs, whom he addresses performatively, in the «Letter of 1492», demanding that they grant him, as promised in the «Capitulaciones de Santa Fe (17 April 1492)» and the "Carta de Merced (30 April 1492)», a title of nobility in keeping with his lofty mission. While the royal documents insisted on Columbus's status as a subject and a vassal, he insists on the separate unfolding of his succession as his family becomes more powerful with each new discovery: ${ }^{9}$

Vuestras Altezas ... me hizieron grandes mercedes y me anobleçieron, que dende en adelante yo me llamase Don y fuesse Almirante Mayor de la mar Occéana y Visorey e Governador perpetuo de todas las islas y tierra firme que yo descubriese y ganasse, y de aquí en adelante se descubriesen y ganasen en la mar Occéano, y así sucediese mi hijo mayor, y él así de grado en grado para siempre jamás. (Varela ed., 16) ${ }^{10}$.

Your Majesties ... granted me great concessions and ennobled me, allowing me to call myself Don from then onwards, with the title of Grand Admiral of the Ocean Sea, and Viceroy and Governor in perpetuity of all the islands and mainland that I might discover and win, or which may be henceforth discovered and won in the Ocean Sea, and you ordained moreover that my eldest should succeed me in this, and so on through future generations forever. (Cummins ed., 82)

This passage summarizes the terms of the commission that he was granted through the "Capitulaciones» and the «Carta de Merced», which were generous in bestowing on Columbus unheard-of privileges (including the new title of viceroy) simply because no one at the time could suspect the magnitude of the lands he was to

9. Although the history of the composition and carly circulation of the «Letter of 1492 » is far from clear, Zamora believes it was written after Columbus's return from his first voyage to America, when he became fully conscious of the way in which he could rhetorically transform what was initially only a trading expedition into a large-scale enterprise of conquest governed by a providential design. This cover letter probably was enclosed with Columbus's revised version of the ship-log that he sent to the Catholic Monarchs, presenting it as a day-by-day record of the navigation («El prólogo al Diarion 16; Reading Columbus 23-24, 27).

10. In chapter 8 of his Crónica de los Reves Católicos, Alonso de Santa Cruz summarizes the privileges granted Columbus in words that restate what Columbus wrote in the «Letter of 1492 » almost verbation (chapter reproduced in Perez 102-05). 
conquer. No sooner did he return than the monarchs realized they had made Columbus legally the most powerful feudal seigneur of Castile, with full legitimate powers to dispense the highest form of justice in his vast dominions (Kadir 66-71). He now held simultaneously the offices of admiral, viceroy, and governor. According to Felipe Fernández-Armestc, this unforeseen development made the Catholic Monarchs «apprehensive and alert to the need to curtail [Columbus's] powers», since such powers were now large enough to threaten «the triumph of a centralizing monarchy.» Commenting on Columbus's thirst for titles of nobility, Fernández-Armesto has also argued that while Columbus was at times able to temper his high pecuniary demands, he could never attenuate his genealogical obsession, which goes from considering himself the new prophet of the Messiah's Second Coming to claiming for his lineage the hereditary title of viceroy (69-72). ${ }^{11}$

Columbus anticipates the belief of the Puritans that God will show his grace to his people in this world by allowing them to pursue and achieve terrestrial goals in America, goals that in turn are realized ad majorem Gloriam Dei. ${ }^{12}$ After the success of the first and second journeys, Columbus recast his earlier role of conqueror into the new role of messenger. Thus, in the «Letter to Prince Juan's Nurse, Doña Juana de la Torre» («Carta a Doña Juana de la Torre, ama del Príncipe Don Juan» [1499]), he explains how he came to serve the Catholic Monarchs for exclusively religious reasons. In this and other autobiographical texts, Columbus silences his earlier pilgrimage, in the late 1480s, through other European courts (notably those of Portugal's João II and England's Henry VII) in search of a sponsor. ${ }^{13} \mathrm{He}$ also neglects to mention the legal bond of vassalage that from the beginning subjected him to the will of Isabel and Fernando, with rights and obligations on both parts. Instead, Columbus chooses to fashion himself as an appointee of God: «Yo vine con amor tan entrañable a servir a estos Príncipes, y e servido de servicio de que jamás se oyó ni vido. Del nuevo cielo y tierra que dezía nuestro Señor por Sant Juan en el Apocalipsi, después de dicho por boca de Isaías, me hizo mensajero y amostró aquella parte» [«I came to serve their Majesties like no one was seen or heard to serve them before, driven by my tender love for them. God made me the messenger of the new heaven and the new earth of which he spoke in the Apocalypse of St. John after having spoken

11. Columbus saw his dynastic ambitions fulfilled when king Fernando restored Diego Colón in the office of Governor of Hispaniola and had him married to the granddaughter of the hereditary Admiral of Castile. On the matter of pecuniary rewards, however, the king made no concessions to him that could supplement the already substantial remittances in gold that reached him intermittently from Hispaniola (Fernández-Armesto 178-79).

12. In one such cosmology, both the monarch and the individual Christian appear as passive subjects of a transcendental plan. It is God who chooses who will fight and defeat His enemies and so enter the Promised Land. This line of interpretation corresponds to what Nader has called the providentialist «letrado theory of history» (best represented by Andrés de Bernáldez) by opposition to the secular, more Machiavellian, «caballero theory of history» (best represented by Diego de Valera). Nader situates the apex of the confrontation between representatives of the two theories in Castile in the 1480 s $(27-30)$.

13. On Columbus's quest for patronage, before and after he removed to Castile in 1488 , see Fernández-Armesto 45-65. 
of it through the mouth of Isaiah, and he showed me where to find it»] (Varela ed., 263-64; my translation). ${ }^{14}$ By means of the word «mensajero» Columbus alludes here to the games with Greek and Roman etymology to which different spellings of his name lent themselves. To give an example, one of his preferred signatures, the GrecoRoman "Christo Ferens», can be made to mean the «transporter or bearer [ferens] of Christ» or even, in a metaphorical extension, «one who bears testimony to Christ's (the Messiah's) Second Coming».15

The references to John and Isaiah evince Columbus's interest in the prophetic aperture of Christian history. Yet he also had an interest in institutional closure, in moments that announce an end to the joint processes of errancy and revolution, ushering in instead a period of stability in which the original prophet and his successors achieve institutional consecration. In the Libro de las profecias, in which Columbus meant to gather all scriptural prophecies of the Terrestrial Paradise that he thought might prefigure his own arrival in the New World, he included the passage from Chronicles I.17 in which Nathan reveals to David God's designs for him:

fui tecum quocumque perrexisti; et interfeci omnes inimicos tuos coram te, fecique tibi nomen quasi unius magnorum, qui celebrantur in terra. Et dedi locum populo meo Israel; plantatibur, et habitabit in eo, et ultra non co[m]movebitur... A[n]nuntio ergo tibi, quod edificaturus sit tibi Dominus domum. Cumque impleveris dies tuos, ut vadas ad patres tuos, suscitabo semen tuum pot fe, quod erit de filiis tuis; et stabiliam regnum eius. (West and Kling eds., 218, 220)

I have been with thee withersoever thou hast gone: and have slain all thy enemies before thee, and have made thee a name like that of one of the great ones that are renowned in the earth. And I have given a place to my people Israel. They shall be planted, and shall dwell therein, and shall be moved no more.... And I declare to thee, that the Lord will build thee a house. And when thou shalt have ended thy days to go to thy fathers, I will raise up thy seed after thee, which shall be of thy sons: and I will establish his kingdom. (West and Kling eds., 219, 221)

14. Isabel of Castile was herself, like the Admiral, an avid reader of St. John's apocalyptic cosmography and of Sir John Mandeville's Book of the Marvels of the World and Voyage through Jerusalem, Asia, and Africa, an interest awakened in her by the travels of her adventurous great-uncle Don Pedro and by two of Columbus's backers, the Observatine Franciscans Fray Antonio de Marchena (her astrologer) and Fray Juan Pérez (one of her confessors). There were also several humanist scholars at her Court, like Andrés de Bernáldez (later to become an important chronicler), who interpreted many momentous episodes during her rule as part of her divine mission to assume the role of the new Virgin Mary, the mother of the redeemer or Messiah who was going to restore the kingdom of God on earth after the conquest of Granada and of the Holy Sepulchre. See West and Kling eds., 56-58; Liss 284-88, 152-61, 254-58.

15. See Kadir 1-2, 32-33, 153-54. 
Thinking no doubt of his own relationship with his earthly lords, the Catholic Monarchs, Columbus yokes together, in the authoritative exercise of applying Scripture to his experiences in America, David's mission to establish a new lineage of prophet-kings (a «house», as he calls it) in Israel and his own mission to found a Columbian dynasty in America. Both are symbolically given perpetuity through the rehearsal of a succession of generations as a material sign of God's promise of redemption to his people. In summary: both Columbus and the Puritans repeatedly intersperse situations of immediate danger with references to events that hark back to a preexisting sacred text and therefore illustrate their assurance of being the protagonists of a divinely ordained scheme.

In the «Letter of 1492» Columbus effectively links his own departure westward with the departure of the Jews and Muslims of Spain:

[E]ste presente año de 1492, después de Vuestras Altezas aver dado fin a la guerra de los moros, que reinavan en Europa, y aver acabado la guerra en la muy grande ciudad de Granada, adonde este presente año, a dos días del mes de Enero, por fuerça de armas vide poner las vanderas reales de Vuestras Altezas en las torres de la Alfambra, que es la fortaleza de la dicha ciudad, y vide salir al rey moro a las puertas de la ciudad, y besar las reales manos de Vuestras Altezas y del Príncipe mi señor, y luego en aquel presente mes, por la informaçión que yo avía dado a Vuestras Altezas de las tierras de India y de un Príncipe que es llamado Gran Can (que quiere dezir en nuestro romançe Rey de los Reyes), como muchas vezes él y sus anteçessores avían enbiado a Roma a pedir doctores en nuestra sancta fe porque le enseñasen en ella, y que nunca el Sancto Padre le avía proveído y se perdían tantos pueblos, cayendo en idolatrías e resçibiendo en sí sectas de perdiçión; y Vuestras Altezas, como cathólicos cristianos y prínçipes amadores de la sancta fe cristiana y acreçentadores d'ella y enemigos de la secta de Mahoma y de todas idolatrías y heregías, pensaron de enbiarme a mí, Cristóval Colón, a las dichas partidas de Indias para ver los dichos prínçipes y los pueblos y las tierras y la disposiçión d'ellas a nuestra sancta fe....; así que, después de aver echado fuera todos los judíos de todos vuestros reinos y señoríos, en el mismo mes de Enero, mandaron Vuestras Altezas a mí que con armada suffiçiente me fuese a las dichas partidas de India.... (Varela ed., 15-16)

In this year of 1492 Your Majesties brought to an end the war against the remaining Moorish kingdom on European soil, terminating the campaign in the great city of Granada, where on 2 January this year I witnessed Your Majesties' royal standards raised by force of arms on the Alhambra, the fortress of that city, and the Moorish king emerge from the gates to kiss Your Majesties' hands and those of My Lord the Prince.

In that same month, on the information which I had given Your Majesties about the lands of India and a ruler known as the Great Khan (which means in Spanish «King of Kings»), of whom I told you that he, like his predecessors, had many times appealed to Rome for men learned in our Holy Faith to instruct 
him, an appeal to which the Holy Father had not responded, and about the many peoples who were being lost through belief in idolatries and the acceptance of religions of damnation, Your Majesties, being Catholic Christians and rulers devoted to the Holy Christian Faith and dedicated to its expansion and to combating the religion of Mahomet and all idolatries and heresies, decided to send me, Christopher Columbus, to those lands of India to meet their rulers and to see the towns and lands and their distribution, and all other things, and to find out in what manner they might be converted to our Holy Faith....

After expelling all the Jews from your kingdoms and territories, in the same month of January Your Majesties commanded me to sail to those regions of India with a suitable fleet.... (Cummins ed., 81-82)

In the passage just quoted, Columbus variously represents his enterprise of conquest as an exodus (the Jews abandon Spain), a crusade (the Christians advance into Granada), and an evangelical mission (the Great Khan and his people wish to be christened). Peggy K. Liss has intelligently noted that here Columbus inverts the actual order of events: by making it look that the Jews' leaving preceded his royal commission (which it did not), he inserts himself in the proper sequence of prophetic conditions announcing the coming of the Last Days, intermingling his personal destiny with that of the monarchs and of the nation (286). Along with the Sephardic exodus and the voyage of Columbus, the main event that caused a major readjustment of power relations in Spain in 1492 was the surrender of Granada, the last Muslim hold over Iberia, to the siege of the Catholic Monarchs. Muslims who declined conversion were also forced, like the Jews of Sepharad, to go into exile. The synchronicity of all three movements of population has been aptly commented upon by maritime historian D.W. Meinig, for whom the events of 1492 were the end-result of a process long in the making. According to Meinig, just as the conquest of Granada simply culminated the Castilian warriors' reclaiming of the richest lowlands of Andalusia, pushing the Muslims progressively to the West, so too was Columbus's first transoceanic voyage

the culmination of a long prelude of Iberian Atlantic reconnaissance and island conquests. Yet this superficial coincidence can be given significant meaning, for it was in thanksgiving for the fall of Granada that Isabel equipped Columbus's expedition, and it is quite appropriate to see the reconquista in Europe and the range of the conquistadores over the Americas as successive phases in the same broad movement: the powerful outward expansion of Western Christian society. Viewed at such a scale these events of 1492 do mark an ending in the Old World, a beginning in the New, and a convenient symbolic concatenation in the larger structure of history. (4)

A well-known phenomenon of early modern Europe was the migration of minority groups from one country to another because of religious persecution. Both 
Columbus and Bradford repeatedly recall situations and events that illustrate the physical and emotional afflictions inherent in this plight. Columbus neatly and cunningly represents the banishment of the Jews and Muslims as the fulfillment of a prophecy-the instauration of the monarchia hispanica. Instead of lamenting the demise of the situation known as convivencia, Columbus mentions approvingly the near-simultaneous surrender of the "Moorish king» and the «expelling [of] all the Jews».

In Of Plymouth Plantation Bradford also devotes several long passages to the topic of banishment and migration, listing the principal motives advising the Pilgrims to choose what he calls «self-removal» and «exile» from England to Holland and on to America. These motives include the impending threat of imprisonment in England; the appearance there of the "plague," which itself takes on a biblical resonance through its intertextual allusion to the «seven plagues of Egypt;» and the series of schisms taking place within Protestantism, which he compares to the «prophets crying out the high places in Israel» (5-7). Furthermore, in Holland the Pilgrims were forced by necessity to seek employment with other Egyptian-like oppressors-the Catholic and Lutheran artisans and merchants-thus «admitting of bondage with danger of conscience» (23-24). 16

Book I of Bradford's work is full of references to the positive and negative aspects of migration. For example, in chapter 4 we read:

After they had lived in this city [of Amsterdam] about some eleven or twelve years (which is the more observable being the whole time of that famous truce between the state and the Spaniards) and sundry of them were taken away by death and many others began to be well stricken in years ... those prudent governors with sundry of the sagest members began both deeply to apprehend their present dangers and wisely to foresee the future and think of timely remedy. In the agitation of their thoughts, and much discourse of things hereabout, at length they began to incline to this conclusion: of removal to some other place. (23)

This series of removals from one place to another, enacted in the form of an exodus from the land of the Pharaonic oppressor (the Stuart king) to the Sodom-like libertine city (Amsterdam) and on to the New World causes the dispersion of the Separatist Church, a veritable diaspora which opens up a new horizon of trials and opportunities for the dissenters. This modern diaspora was to entail, first of all, the spread of the true faith and its testing in what Bradford called, deliberately and hyperbolically, a «desolate wilderness.» As is well known, although the Mayflower

16. On Bradford's exaggeration of the dissoluteness of Amsterdam and Leyden, designed to hide the Separatists" fear of assimilation in the «lovely hospitable cities» of the Dutch provinces, see Gay 27-29. 
Pilgrims were quick to realize the vast natural resources of Massachusetts (as made clear in the collective work known as Mourt's Relation: A Journal of the Pilgrims at Plymouth, written between the years 1620 and 1621), Bradford, as civil and religious leader, shows a marked tendency to uglify the New World by making it resemble the deserts, the wildernesses, and other hellish places found in the Bible. ${ }^{17}$

The main drawback to the enactment of a diaspora is the dilution, hybridization, and ultimate weakening of the original culture and faith as the members of the group move farther away from the center where their identity originated. By the time Bradford set out to write his history, the Mavflower colonists were no longer destitute immigrants in a strange land. They were now living in the vicinity of John Winthrop's Middle-Way Congregationalists, whose colony and church provided the nucleus of the genteel and commercial Boston in the later seventeenth century. Bradford was quick to apprehend that the economic prosperity of his neighbors (a prosperity announced in Old Testament texts, from Moses to Jeremiah) was to bring about the diaspora of the Pilgrims in the New World. As both Separatists and Nonseparatists found additional signs of their elect status in the thriving prosperity of some of their fellow Puritans, they also felt the temptation to go westward, in search of more land to explore and claim for themselves. This situation replicates Columbus's inveterate tendency to go always plus ultra -he wishes to «descubrir y ganar nuevas tierras» as he puts it in the Journal of the First Voyage -instead of staying in the places over which he has already claimed jurisdiction.

Bradford's role in the early stages of New England history is twofold: as a historical agent, he participated directly in the creation of the first «community of saints» in America; and as a historical writer. he narrated retrospectively the vicissitudes of the foundation of the first Puritan colony in America (in Book I of $O f$ Plymouth Plantation), and chronicled its eclipse against the background of Massachusetts Bay's rise (in Book II). At the moment of writing Book I, in 1630, Bradford was aware that the Plymouth settlers now looked at the Massachusetts Bay Colony as the place where the promise made to Abraham and Moses of a new Canaan could be achieved. Here the two alternate articulations of history and progress studied by Bercovitch came into play. Plymouth, on the one hand, with its shortage of lands and its policy of voluntary isolation, represented a single episode in the history of successive flourishings and decays (or redemptions and declensions). Massachusetts Bay, on the other, represented to the world the foundation of a godly city on earth. Almost from the beginning. Plymouth was overshadowed by Massachusetts Bay, into which it was merged in 1691, when the New Charter for the colony was approved.

By contrast with Bradford's Separatist ploughmen, Winthrop's Puritan tradesmen did not rejoice in their isolation from England nor did they welcome the additional hardships and trials involved in settling down in America. Instead, they willingly took the less traumatic path of progressively reforming their doctrines to make them fit their immediate need to achieve economic success and emotional 
relaxation. This success would be later equated, during the years of the Antinomian controversy, with assurance of eternal salvation. But Bradford was not prepared to make such concessions, not even in 1644, when he sat down to write chapter 34 of Book II, in which he strikes an elegiac note in the representation of Plymouth's decay:

And thus was this poor church left, like an ancient mother grown old and forsaken of her children, though not in their affections yet in regard of their bodily presence and personal helpfulness; her ancient members being most of them worn away by death, and these of later time being like children translated into other families, and she like a widow left only to trust in God. Thus, she that had made many rich became herself poor. (334) ${ }^{18}$.

Columbus uses the imagery of the Israelite exodus and the centrifugal movement of populations to legitimate his own process of upward social mobility. Bradford actualizes a similar diasporic movement in his representation of Plymouth as an old mother who has been abandoned physically and economically by her ambitious younger children. Neither Columbus nor Bradford realizes the dream of genealogical continuity in which the parents transmit their authority and their spiritual and material patrimony to their children. In the years when he wrote each and every one of the episodes involving an exodus-like movement, Bradford knew that the Separatist experiment at Plymouth was bound to fail. It probably did not surprise him that a large number of second-generation colonists already chose to place themselves under the tutelage of a Nonseparatist Puritan colony (Massachusetts Bay), a decision that was to grant them new opportunities for social and economic betterment. ${ }^{19}$

What a joint reading of Columbus and Bradford teaches us is that the language of religious emancipation is inextricably bound up with the language of economic promotion. Both discourses insist on the self-differentiation of the individual Christian, first from the alien culture constructed as an other, and later from one's own community. Columbus's ambitions to become Grand Admiral of the Ocean Sea and have that title inherited by his descendants are parallel to the desire of the first-generation Plymouth colonists to have their children follow in their doctrinal footsteps, to define their identity not as colonists of a fertile land but as custodians of a legacy of persecution and suffering. Columbus's and Bradford's respective emphases on the exilic and nomadic condition of their pursuits result as much from the authority of the biblical intertext of Exodus as they do from the realization that the as-yet unclaimed American territories in which they landed opened up a whole new horizon of possibilities for the economic and social amelioration of their families and their churches.

18. For a detailed reading of this passage that emphasizes Bradford's sense of personal loss and betrayal, see Franklin 168-69.

19. In a well-argued essay on the various strands of Puritan utopianism, Peñalba García provides an apt summary of the dilution of Plymouth's ideals into those of Massachusetts Bay (130-35). 


\section{WORKS CITED}

Bercovitch, Sacvan. «Puritan New England Rhetoric and the Jewish Question.» Early American Literature 5 (1970): 63-73.

- The Rites of Assent: Transformations in the Symbolic Construction of America. New York: Routledge, 1993.

Bradford, William. Of Plymouth Plantation, 1620-1647. Ed. Samuel Eliot Morrison. New York: Knopf, 1952.

Cartelli, Thomas. «Transplanting Disorder: The Construction of Misrule in Morton's New English Canaan and Bradford's Of Plymouth Plantation.» English Literary Renaissance 27 (1997): 258-80.

Cummins, JOHN, ed. The Voyage of Christopher Columbus: Columbus' Own Journal Newly Restored and Translated. New York: St. Martin's, 1992.

Fernández-Armesto, Felipe. Columbus. New York: Oxford UP, 1991.

Franklin, Wayne. Discoverers, Explorers, Settlers: The Diligent Writers of Early America. Chicago: U of Chicago P, 1979.

Gay, Peter. «William Bradford: Caesar in the Wilderness.» A Loss of Mastery: Puritan Historians in America. New York: Vintage, 1968.

Hovey, Kenneth alan. «The Theology of History in Of Plymouth Plantation and Its Predecessors», Early American Literature 10 (1975): 47-66.

Jehlen, Myra. The Literature of Colonization. The Cambridge History of American Literature, Volume One: 1590-1820. Gen. ed. Sacvan Bercovitch. New York: Cambridge UP, 1994. 11-168.

Kadir, Djelal. Columbus and the Ends of the Earth: Europe's Prophetic Rhetoric as Conquering Ideology. Berkeley: U of California P, 1992.

Liss, Peggy K. Isabel the Queen: Life and Times. New York Oxford UP, 1992.

Meinig, D.W. Atlantic America, 1492-1800. The Shaping of America: A Geographical Perspective on 500 Hundred Years of History. Vol. 1. New Haven: Yale UP, 1986.

Nader, Helen. The Mendoza Family in the Spanish Renaissance, 1350-1550. New Brunswick: Rutgers UP, 1979.

Pagden, Anthony. Spanish Imperialism and the Political Imagination. New Haven: Yale UP, 1990.

Peñalba García, Mercedes. «Visiones eutópicas de América en la identidad colonial puritana.» Revista Alicantina de Estudios Ingleses 2 (1989): 127-42.

Pérez, Joseph. La España de los Reyes Católicos. 1986. Madrid: Información y Revistas, 1992.

Rodríguez García, José María. «From the Communal "We" to the Individual "I": The Rhetoric of Self-Legitimation in Bernal Díaz's Historia.» Revista de Estudios Hispánicos 31 (1997): 475-503.

Varela, Consuelo, ed. Cristóbal Colón. Textos y documentos completos. Madrid: Alianza, 1982.

Wenska, Walter P. «Bradford's Two Histories: Pattern and Paradigm in Of Plymouth Plantation». Early American Literature 13 (1978): 151-64. 
West, Delno C. \& August Kling, eds. The Libro de las profecías of Christopher Columbus: An en face Edition. Trans. and commentary by West and Kling. Gainesville: U of Florida P, 1991.

Zagorin, Pérez. Societies, States, and Early Modern Revolutions: Agrarian and Urban Rebellions. Vol. 1 of Rebels and Rulers, 1500-1660. New York: Cambridge UP, 1982.

Zamora, Margarita. «El prólogo al Diario de Cristóbal Colón». Ínsula 522 (June 1990): 16-17.

—. Reading Columbus. Berkeley: U of California P, 1993. 